\title{
The impact of marketing strategy on logistics decisions and the implementation of JIT
}

\author{
Eszter Sós*, Péter Földesi \\ Széchenyi István University, Department of Logistics and Forwarding \\ H-9026 Győr, Egyetem tér 1. \\ *e-mail: sos.eszter@sze.hu
}

Submitted: 12/02/2021; Accepted: 30/04/2021; Published online: 03/05/2021

Abstract: Marketing has a significant impact on logistics systems and corporate performance, so it is nowadays necessary to define a marketing logistics strategy in the lives of larger companies so that logistics decisions are not distorted by the marketing strategy. According to the current direction of development, smaller and smaller quantities of goods are constantly being moved, with ever shorter deadlines. Therefore, companies prefer to use the Just In Time (JIT) system, which results in a gradual reduction in inventory costs, but increases the burden on the environment. In this article, we analyze the interaction between marketing and logistics and the logistics environment required to implement a JIT system. For research we have used the matrix of Quality Function Deployment (QFD) technique to evaluate the needs of the customer with respect to the JIT system, thus clarifying the logistics strategy applicable to the introduction of the specific product.

Keywords: logistics; marketing strategy; JIT; QFD

\section{Introduction}

The organizational structure of companies has undergone significant changes in recent decades due to the competitive situation in the market. Meeting customer expectations at the highest possible level has come to the fore, and marketing has gained more and more ground. Customer service also requires a well-established logistics system, so it is necessary to define a marketing logistics strategy when developing corporate strategies. By applying it, it is possible to avoid that the 
developed marketing concepts distort logistics decisions and to introduce a logistics system for which the company's logistics environment is not yet prepared.

The aim of our article is to describe the importance of marketing-logistics strategy to meet customer expectations and to conduct an examination of the logistics environment required to implement the JIT system, using the QFD technique matrix. The intent of the QFD technique is to meet the highest possible level of consumer needs through the design of manufacture and production design processes developed by engineers, taking into account customer expectations. [1]

The QFD method can be effectively applied in the field of logistics. It can be used to identify the logistics sub-processes that help to meet the primary customer needs.

\section{The role of logistics and marketing in the sales system}

We will describe the interaction between logistics and marketing through the sales system, as the efficiency of a company's logistics system is reflected in the quality of customer service [2].

Objectives to be defined during the examination of the operation of the sales systems: examination of the market coverage and development of the sales system taking into account the characteristics of the product, as well as ensuring the quality of service and achieving profitability. Of the operational goals listed, logistics ensures the right level of service and partly profitability, while marketing covers the rest [3].

The efficiency of logistics services has an impact through the quality of customer service, as the product is sold to the user together with the contributing services. Therefore, it is important that the logistics concept is completed as soon as the marketing schedule and strategy related to the product is defined. To meet the highest possible level of customer needs, it requires a unified management of logistics and marketing, as proper customer service includes optimal delivery time, quality and flexible delivery, as well as delivery skills and the ability to respond appropriately to suddenly increased demands [4]. Logistics is a means to achieve marketing targets, as marketing stimulates demand and transmits market impulses to production; logistics executes demand and implements production-related flow processes [5].

From the point of view of both logistics and marketing, the right IT background is essential for a company, as this will allow a faster and more accurate information flow. This will reduce uncertainty and thus reduce safety stocks, while keeping the proportion of inaccurate, defective and non-scheduled deliveries to a minimum [6]. 
The information system that supports the operation of the company must provide data from the inside - about the needs of the company and the possibilities of substitution, and from the outside - about the needs of the market, suppliers, and our reliability and costs.

\section{Examining the conditions necessary for the development of a logistics strategy}

An important part of the corporate strategy is the logistics strategy, the main content elements of which are the purchasing and inventory strategy, as well as the physical distribution, information flow and waste management logistics strategy, but nowadays we also list the marketing logistics strategy. From the point of view of marketing - logistics, the following general requirements and objectives related to purchasing and sales can be defined during the development of the strategy. Purchasing - supply side requires short delivery times, flexible supplier relationships, and low inventory management costs. On the sales - distribution side, in addition to short delivery times, adequate delivery quality and readiness, the reliability of delivery and the ability to respond flexibly to unforeseen situations are of paramount importance [7].

In many cases, marketing strategy distorts logistics decisions, which is why the Just In Time system is often used even where the corporate environment is not properly prepared yet. For this reason, it is essential to examine the logistics environment, order sizes, the need for JIT, and the environmental burdens it causes before implementing the Just In Time system.

\section{The Just In Time system production philosophy}

Just In Time is a general philosophy, a principle of production, organization and management that is often and erroneously used as a synonym for out-of-stock production. JIT is a pull system, i.e. the production of the product, the flow of material can only start on a specific order or instruction, and so the material is actually just in time, it is not waiting in the system, as it is already waiting for it. Its operations fight for cost reduction, service and quality improvement through loss reduction, employee involvement, and continuous process improvement [8].

The importance of Just In Time today lies in speeding up and simplifying the flow of material and information, reducing costs, minimizing inventory levels, and helping to meet consumer needs. The JIT system seeks to ensure that the raw materials, semi-finished and finished products required for production are available in just the right place, in the right quality and in the right quantity to serve efficient and smooth production, preferably in such a way that their "destination" is as short 
as possible, and be the most cost effective. For the sake of this cost-effectiveness, they do not store only what is absolutely necessary, so stocks of raw materials, semifinished and finished products are kept to a minimum and more frequent deliveries are used [9].

\subsection{Examination of possible application of Just In Time}

The appropriate conditions for the applicability of JIT must be examined in all cases, because not all companies are suitable for the introduction of JIT. The first step is to explain the tasks to the management and monitor what obstacles are present in the corporate environment (Table 1).

Table 1. Examination of possible application of Just In Time

\begin{tabular}{|c|c|}
\hline $\begin{array}{c}\text { Key responsibilities of management } \\
\text { when implementing JIT }\end{array}$ & Barriers to JIT implementation \\
\hline $\begin{array}{l}\text { You need to be deter } \\
\text { losses in the processes. }\end{array}$ & $\begin{array}{l}\text { Lack of commitment from top } \\
\text { management. }\end{array}$ \\
\hline You need to be committed to innovation. & \multirow{2}{*}{ Lack of plans to obtain support. } \\
\hline $\begin{array}{l}\text { A flexible produ } \\
\text { set up with spare }\end{array}$ & \\
\hline $\begin{array}{l}\text { A well-motivated and flexible workforce is } \\
\text { needed. }\end{array}$ & itude of employees, lack of \\
\hline $\begin{array}{l}\text { In quality, a "zero error rate" approach } \\
\text { should be pursued. }\end{array}$ & luct quality. \\
\hline pliers must be selected. & \multirow{4}{*}{$\begin{array}{l}\text { Reluctant cooperation and } \\
\text { willingness of the supplier to } \\
\text { cooperate. }\end{array}$} \\
\hline $\begin{array}{l}\text { A long-term relationship with suppliers } \\
\text { needs to be established. }\end{array}$ & \\
\hline $\begin{array}{l}\text { You need to be prepared for smaller and } \\
\text { more frequent deliveries. }\end{array}$ & \\
\hline Reliable delivery times are required. & \\
\hline $\begin{array}{l}\text { Establishing a close communication } \\
\text { relationship with suppliers. }\end{array}$ & $\begin{array}{l}\text { Weaknesses in the supply chain } \\
\text { communication system. }\end{array}$ \\
\hline
\end{tabular}

\subsection{The basic elements of Just In Time implementation}

Management and employees can be made fit to implement JIT through training, but the proper design of physical conditions is also at least as important as improving 
the thinking of the workforce at the system level. The adaptation and preparation of the work environment begins with an examination of the logistics environment, which includes an examination of the need for a JIT.

We would like to describe the basic elements needed to build Just In Time (Table 2 ), the existence of which is worth reviewing before introducing the system.

Table 2. The basic elements of Just In Time implementation

\begin{tabular}{|l|l|}
\hline \multicolumn{2}{|c|}{ Basic elements needed to design a Just In Time system } \\
\hline Puller system & $\begin{array}{l}\text { The manufacturer starts production of the product to } \\
\text { a specific order according to the user's needs. }\end{array}$ \\
\hline $\begin{array}{l}\text { Constant production } \\
\text { volume }\end{array}$ & $\begin{array}{l}\text { Constant flow of material between operating sites, } \\
\text { accurate timing of all activities. }\end{array}$ \\
\hline Low stock & $\begin{array}{l}\text { JIT is created as a result. Advantages: less storage } \\
\text { space and tied up capital. }\end{array}$ \\
\hline Small items & $\begin{array}{l}\text { It reduces inventory costs and space requirements. If } \\
\text { there is a quality problem, fewer products need to be } \\
\text { repaired or reworked. }\end{array}$ \\
\hline Fast, low-cost change-over & $\begin{array}{l}\text { Small production batches assume frequent switching, } \\
\text { which should be cheap and feasible. Conversion } \\
\text { losses can be reduced by having similar products } \\
\text { follow each other. For this reason, proper } \\
\text { involvement of the workforce is necessary. }\end{array}$ \\
\hline $\begin{array}{l}\text { Operation order suitable } \\
\text { for the purpose }\end{array}$ & $\begin{array}{l}\text { JIT systems are product-oriented, mostly based on } \\
\text { material flow layout. }\end{array}$ \\
\hline $\begin{array}{l}\text { Effective } \\
\text { maintenance }\end{array}$ & $\begin{array}{l}\text { Applying a preventive and forward-looking } \\
\text { maintenance method is important because a machine } \\
\text { failure can ruin the production schedule. }\end{array}$ \\
\hline $\begin{array}{l}\text { Multidisciplinary, multi- } \\
\text { tasking staff }\end{array}$ & $\begin{array}{l}\text { Those working with the JIT system should be able to } \\
\text { diagnose problems, eliminate minor faults, and be } \\
\text { proficient in work at other workplaces. }\end{array}$ \\
\hline $\begin{array}{l}\text { Ability to work together to } \\
\text { solve problems }\end{array}$ & $\begin{array}{l}\text { A high degree of cooperation between employees is } \\
\text { essential for the effective operation of JIT, and special } \\
\text { attention must be paid to developing this skill before } \\
\text { introducing a JIT system. }\end{array}$ \\
\hline Continuous improvement & $\begin{array}{l}\text { Directions: inventory reduction, mitigation of } \\
\text { transition times and their costs, improvement of } \\
\text { quantity and quality, depreciation of losses. }\end{array}$ \\
\hline
\end{tabular}


It can be clarified from Table 2 that the examination of the logistics environment covers all areas of the company. I present in Table 3 the supplier expectations outside the company, which play an important role in the implementation of JIT.

Table 3. Requirements from the supplier

\begin{tabular}{|l|l|}
\hline \multicolumn{2}{|c|}{ Supplier expectations for the development of Just In Time } \\
\hline Reliable suppliers & $\begin{array}{l}\text { In a JIT system, a good supplier-customer relationship is } \\
\text { very important. Expectations of suppliers are: consistently } \\
\text { high quality, flexibility, frequency, delivery in small } \\
\text { batches and quick resolution of any problems encountered. }\end{array}$ \\
\hline High quality level & $\begin{array}{l}\text { The number of incoming materials without a given } \\
\text { quantity, without "retention", so a high level of quality is } \\
\text { both a prerequisite and a result of JIT operation. In case of } \\
\text { a defective piece, identification and replacement are } \\
\text { important. }\end{array}$ \\
\hline $\begin{array}{l}\text { Strong IT connection, } \\
\text { communication } \\
\text { between buyer and } \\
\text { supplier }\end{array}$ & $\begin{array}{l}\text { The management systems of the two organizations must } \\
\text { work closely together. }\end{array}$ \\
\hline
\end{tabular}

In the Just In Time system reliability is a basic requirement, as it does not include a security set, in addition to this essential condition for its implementation is an upto-date knowledge of consumer needs and the construction of the necessary IT network [10].

\section{Impact of marketing strategy on the JIT system}

Whether the Just In Time system should be served or whether the company has a traditional supplier role has a significant influence on the design side of the marketing logistics strategy.

Examining the management competencies required to implement JIT and the basic elements identified for implementing the system described in the previous chapter is essential when developing a marketing strategy, as a poorly chosen marketing strategy can easily distort logistics decisions and implement a JIT system that is not suitable. When designing the distribution side of a marketing-logistics strategy, it is necessary to examine the characteristics of the logistics environment that will help select the right logistics system for the company. [11]

It is necessary to know what principles and goals should be applied during the development of the distribution logistics system. To do this, the company's 
management must determine the criteria on the basis of which the finished product storage system and the unit load training applied to the finished product structure should be selected.

The direct delivery of the product from the finished goods warehouse, the means of warehousing technology and the picking method used also have a significant influence on the development of the logistics environment. In order to determine the range of potential suppliers, it is necessary to know what modes of transport and priorities are used.

In terms of product deliverability, it is necessary to examine for which products it is possible to deliver the finished product directly from the end of the production lines, and for which products it is advisable to use distribution warehouses during the distribution logistics activity. In order to carry out the distribution activity, an IT and information system must be set up that adequately supports its product identification.

It must be determined which management-, leadership- and controlling system must be developed for the distribution activity, and it is also necessary to establish a quality assurance system applied during the distribution logistics process.

Examining the criteria above, the answers are clearly provided by the Just In Time system, as a regulated environment is essential for its proper functioning. But what happens when we don't take into account the specific needs of JIT while developing a marketing strategy?

On the one hand, it distorts logistics decisions, so JIT can be introduced in a company where the company's logistics environment is not suitable for it yet. On the other hand, the determination of order batch sizes is not adapted to the scheduled material supply of the logistics system, so marketing may be successful, but the logistics system (production, delivery, etc.) is not prepared for the order quantity, so the customer has to wait for the product, which in many cases can lead to customer dissatisfaction. In addition, increased demand may necessitate unplanned deliveries, which cause a high environmental burden.

The Just In Time system is only viable with a certain level of stability of supply and demand [12], so efforts should be made to consider the logistics environment from both the supplier and the sales company when making marketing logistics decisions. On the one hand, this is important for the proper and cost-effective operation of the JIT system, and on the other hand, a malfunctioning JIT system generates occasional deliveries, which leads to environmental damage. 


\section{Environmental loads caused by JIT}

Most of the literature deals with the benefits of the Just In Time system, the environmental effects it causes are not described. In 2007, the European Parliament already addressed the issue of freight transport in its report on trade and climate change (2007/2003 (INI)), with particular reference to the negative effects of the Just In Time system on the environment [13].

The Just In Time system is designed to eliminate stock, but due to frequent deliveries, a significant increase in shipping volume is expected. In addition, it is important that the transport of goods is carried out with sufficient flexibility and precision, so that the movement of goods is mostly carried out by road, which in turn causes a significant environmental burden in terms of pollutants, toxic gases and noise [14].

In the European Union the road transport is responsible for $72 \%$ of $\mathrm{CO}^{2}$ emissions from transport, of which $38.1 \%$ can be related to freight transport [15], so one of the important logistical factors in terms of environmental impact is the emission of pollutants from material handling activities [16]. Rail freight emits about $65 \%$ less $\mathrm{CO}_{2}$ than road freight transport [17], but rail freight is not always feasible due to track constraints and unreliability to serve the strict schedule of the JIT system.

Due to frequent deliveries, the amount of packaging materials can also increase, as units are usually set up as required by the company and quality control is also done before delivery. Therefore, the parts are delivered to the user company in such a way that their inspection and handling takes as little time as possible, so in order to protect the quality of the goods, more packaging material is used than in preparation for delivery. In addition, many suppliers do not invest energy or time and money in the development and use of multi-way packaging systems, but use cheaper and logistically easier-to-use one-way packaging materials, which become waste immediately upon arrival and therefore have a significant impact on the environment.

\section{Examining customer needs for Just in Time using QFD technique}

Quality Function Deployment (QFD) is a technique used by service providers to gather requirements, expectations, and customer purchasing decision factors [18]. A practical formalism of transforming consumer needs into technical, quality features is the House of Quality - (HOQ) [19].

In this article we use the matrix that forms the basis of the QFD technique, which gives the "trunk" of the House of Quality (HOQ). We chose this technique because, 
with the help of QFD, consumer needs can be compared with logistics processes, thus making it possible to meet the needs of consumers at the highest possible level [20].

In addition to consumer needs, the elements of the 6R principle (The 6 Rights of Logistics) used in logistics were included in the matrix, and the basic elements necessary for the development of the JIT system were contained as technical characteristics.

Essential elements for implementing

JIT system
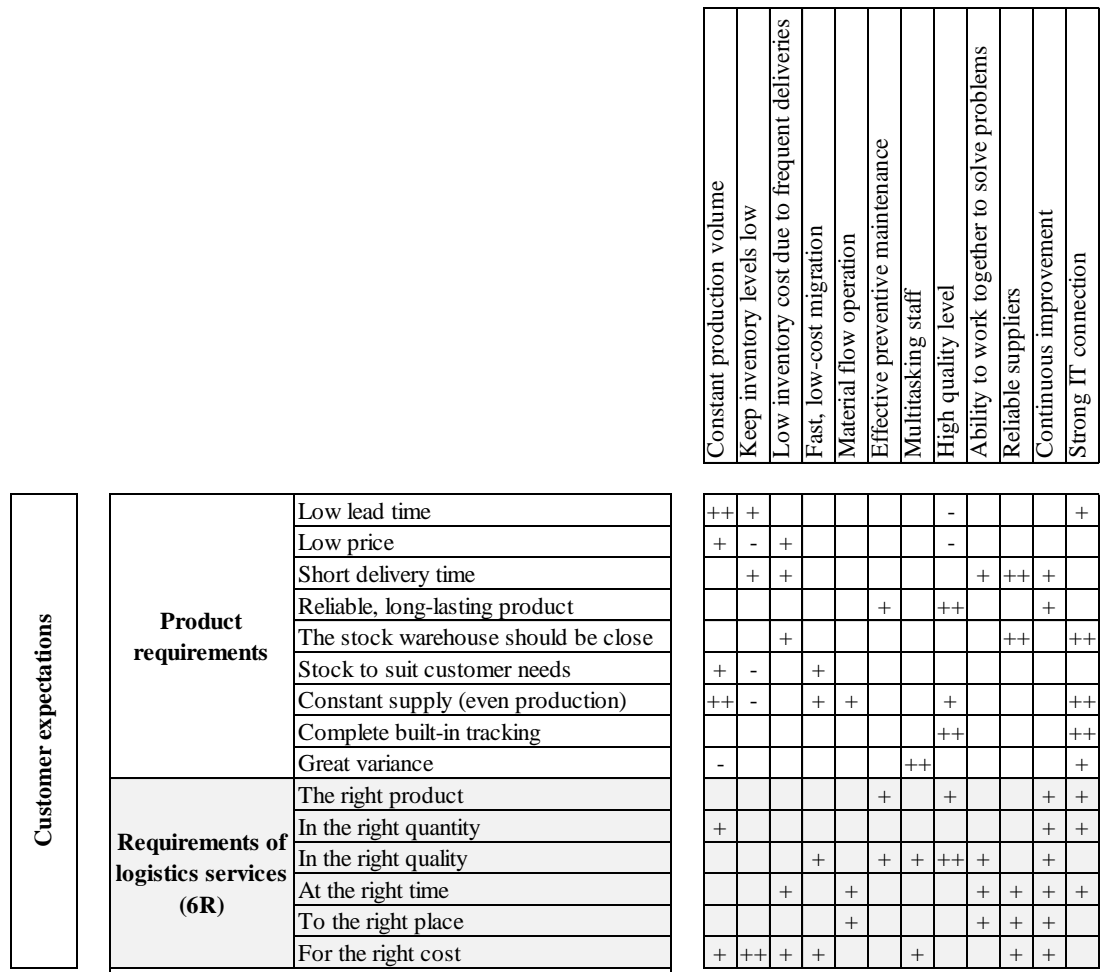

\begin{tabular}{|c|c|}
\hline \multirow{9}{*}{$\begin{array}{c}\text { Product } \\
\text { requirements }\end{array}$} & Low lead time \\
\hline & Low price \\
\hline & Short delivery time \\
\hline & Reliable, long-lasting product \\
\hline & The stock warehouse should be close \\
\hline & Stock to suit customer needs \\
\hline & Constant supply (even production) \\
\hline & Complete built-in tracking \\
\hline & Great variance \\
\hline \multirow{6}{*}{$\begin{array}{c}\text { Requirements of } \\
\text { logistics services } \\
(6 R)\end{array}$} & The right product \\
\hline & In the right quantity \\
\hline & In the right quality \\
\hline & At the right time \\
\hline & To the right place \\
\hline & For the right cost \\
\hline \multicolumn{2}{|l|}{ Legend } \\
\hline++ & Significant positive effect \\
\hline+ & Moderate positive effect \\
\hline- & Can cause a negative effect \\
\hline
\end{tabular}

Figure 1. Examination of customer expectations for JIT using QFD technique 
In the intersections of the present matrix, we used the symbols according to the relevance of the given relationship. In the legend, we clarified what meanings we associated with the different symbols. During the analysis according to the whole QFD technique, the symbols are replaced by quantified data, so that the values can be weighted with Fuzzy later. In this way, the customer's needs for the JIT system in relation to the product and logistics services can be evaluated.

The developed system can be used primarily in the commercial field, as it helps to develop the logistics strategy of the products purchased as a result of the marketing strategy. However, it can also be used in an industrial environment for any product that is made to meet specific customer needs (e.g. a custom-made car).

It can be used as a decision tool in all areas where strategic logistics development is required. By using it, the logistics processes become clearer and the goals set by the customer are easier to achieve. Existing logistics strategies (e.g. Push and Pull logistics strategy) can also be reviewed with it.

By applying the OFD technique in the field of logistics, an analysis can be made of the already developed logistics strategies, which also points out the shortcomings of the logistics environment.

\section{Conclusion}

One of the important logistics problems today is the scheduling of deliveries. Companies strive to keep their inventories low, resulting in lower inventory management costs and tied-up capital.

For this reason, the pursuit of a Just In Time system is popular, but in many cases it is also introduced by companies whose logistics environment is not suitable for using the system. Prior to implementation, it would be necessary to coordinate marketing strategy decisions with the logistics environment, as a poorly chosen marketing strategy decision causes significant negative effects on logistics processes, resulting in the customer not receiving the purchased goods on time. The efficiency of a company's logistics system is reflected in the quality of customer service, so a successful Just In Time system causes satisfaction for both the supplier and the customer.

In order to determine the appropriate logistics strategy, we applied the procedure and matrix of the QFD technique. During the evaluation of the matrix, we examined the customer needs in terms of the basic conditions required for the development of the JIT system, thus clarifying the applicability of the JIT system when introducing the given product. 


\section{References}

[1] Y. Akao, QFD: Past, Present, and Future, in: 3rd International Symposium on Quality Function Deployment (ISQFD'97), 1997, Linköping, pp. 1-12. URL

http://www.las.inpe.br/ perondi/19.10.2009/Akao_1997_QFD_ History.pdf

[2] V. E. Bottani, A. Rizzi, Strategic management of logistics service: A fuzzy QFD approach, International Journal of Production Economics 103 (2) (2006) pp. 585-599.

doi: https://doi.org/10.1016/j.ijpe.2005.11.006

[3] M. S. Akdogan, A. Durak: Logistic and marketing performances of logistics companies: A comparison between Germany and Turkey, Procedia - Social and Behavioral Sciences 235 (2016) pp. 576 -586.

doi: https://doi.org/10.1016/j.sbspro.2016.11.084

[4] A. E. Ellinger: Improving Marketing/Logistics Cross-Functional Collaboration in the Supply Chain, Industrial Marketing Management 29 (1) (2000) pp. 85-96.

doi: https://doi.org/10.1016/S0019-8501(99)00114-5

[5] P. V. Hong, T.-T. Nguyen: Factors affecting marketing strategy of logistics business - Case of Vietnam, The Asian Journal of Shipping and Logistics 36 (4) (2020) pp. 224-234.

doi: https://doi.org/10.1016/j.ajsl.2020.03.004

[6] A. P. Barbosa-Povoa, J. M. Pinto: Process supply chains: Perspectives from academia and industry, Computers \& Chemical Engineering 132 (2020) 106606.

doi: https://doi.org/10.1016/j.compchemeng.2019.106606

[7] J. Salkovska, N. R. V.Danovics: Marketing and Logistics Cooperation Problems in Latvian Companies, Procedia - Social and Behavioral Sciences 110 (2014) pp. 390-397.

doi: https://doi.org/10.1016/j.sbspro.2013.12.883

[8] T. C.E. Cheng, S. Podolsky: Just-In-Time Manufacturing: An Introduction, Chapman \& Hall Second Edition (1996) ISBN: 0-412-73540-7. 
[9] K.-H. Lai, T. C.E. Cheng: Just-In-Time Logistics, MPG Books Ltd. (2009).

[10] R. Z. Farahani, S. Rezapour, L. Kardar: Logistics operations and management: Concepts and models, Elsevier (2011). doi: https://doi.org/10.1016/C2010-0-67008-8

[11] U. Y. Alvarado, H. Kotzab: Supply Chain Management: The Integration of Logistics in Marketing, Industrial Marketing Management 30 (2) (2001) pp. 183-198.

doi: https://doi.org/10.1016/S0019-8501(00)00142-5

[12] C. H. Pragman: JIT II: A purchasing concept for reducing lead times in timebased competition, Business Horizons 39 (4) (1996) pp. 54-58.

doi: https://doi.org/10.1016/S0007-6813(96)90052-X

[13] European Parliament, Trade and climate change 2007/2003(INI), (2007). URL

https://www. europarl.europa.eu/sides/getDoc. do?pubRef=$/ / E P / / T E X T+R E P O R T+A 6-2007-0409+0+D O C+X M L+V O / / H U$

[14] A. Memari, A. Rahman, A. Rahim, N. Absi, R. Ahmad, A. Hassan: Carboncapped Distribution Planning: A JIT Perspective, Computers \& Industrial Engineering 97 (2016) pp. 111-127.

doi: https://doi.org/10.1016/j.cie.2016.04.015

[15] European Environment Agency (2016).

URL www.eea.europa.eu/hu

[16] Z. Chena, B. Bidanda: Sustainable manufacturing production-inventory decision of multiple factories with JIT logistics, component recovery and emission control, Transportation Research Part E 128 (2019) pp. 356-383. doi: https://doi.org/10.1016/j.tre.2019.06.013

[17] Guidelines for Measuring and Managing $\mathrm{CO} 2$ Emission from Freight Transport Operations (2020).

URL

https://www.ecta.com/resources/Documents/Besto20Practices ○20Guidelines/guideline_for_measuring_and_managing_co2.pd f 
[18] M. M. H. Chowdhury, M. A. Quaddus: A multi-phased QFD based optimization approach to sustainable service design, International Journal of Production Economics 171 (2) (2016) pp. 165-178.

doi: https://doi.org/10.1016/j.ijpe.2015.09.023

[19] D. R. Kiran: Quality Function Deployment, Total Quality Management, Key Concepts and Case Studies (2017) pp. 425-437.

doi: https://doi.org/10.1016/B978-0-12-811035-5.00030-1

[20] A. M. Oddershede, L. E. Quezada, J. E. Valenzuela, P. I. Palominos, H. Lopez-Ospina: Formulation of a Manufacturing Strategy Using the House of Quality, Procedia Manufacturing 39 (2019) pp. 843-850.

doi: https://doi.org/10.1016/j.promfg.2020.01.417

(c) (i) $\$$ This article is an open access article distributed under the terms and conditions of the Creative Commons Attribution NonCommercial ( $C C B Y-N C$ 4.0) license. 